\title{
Cell-mediated immune reaction to colon altered by bacteria
}

\author{
SIDNEY FINK AND ROLAND F. MAIS \\ From the Veterans Administration Hospital, Hines, Illinois, USA
}

It has been suggested that enteric bacteria initiate a destructive immunological reaction in ulcerative colitis either because of antigenic similarity to colon (Perlmann, Hammarström, Lagercrantz, and Gustafsson, 1965) or by acting as a hapten (Kirsner, 1965). If this immunity is of the cell-mediated type, it may be demonstrated by a local reaction following intradermal inoculation with a test antigen (Humphrey, 1967). We therefore tested normal adults and patients with ulcerative colitis for skin sensitivity to colon treated with $E$. coli, colon alone, and $E$. coli alone.

\section{MATERIAL AND METHODS}

PATIENTS Ambulatory adult males free of known intestinal disease and adult males with well established diagnoses of chronic ulcerative colitis were tested. The patients with ulcerative colitis all showed marked proctoscopic abnormalities, grade 2 to 4 (Dragstedt, Dack, and Kirsner, 1941), at the time of the investigation. Several had been receiving salicylazosulphapyridine (Azulfidine) for one to two and a half years (Table I) but none received steroids during the past year.

PREPARATION OF ANTIGENS I Colon tissue was obtained by bite-biopsy of rectal mucosa at the level of the lowest valve of Houston. The specimen was washed vigorously with sterile isotonic saline, placed in $3 \mathrm{ml}$ of sterile saline per $0.05 \mathrm{~g}$ of tissue, and homogenized at $800 \mathrm{rpm}$ for two minutes. The homogenate was stored at $5^{\circ} \mathrm{C}$ and used within 36 hours. In these experiments, $0.5 \mathrm{ml}$ of the homogenate (approx. $8 \mathrm{mg}$ ) plus $1.0 \mathrm{ml}$ saline were incubated in a water bath at $37^{\circ} \mathrm{C}$ for two hours, then sterilized by transferring to a plastic tube ${ }^{1}$ modified according to Fig. 1, and mixing with $0.15 \mathrm{ml}$ of $5 \%(\mathrm{v} / \mathrm{v})$ beta-propiolactone (Betaprone). ${ }^{2}$ Chemical sterilization was facilitated by incubation of these chambers at $37^{\circ} \mathrm{C}$ for two hours (Hartman and LoGrippo, 1957). At this point the chambers contained sterile colon homogenate and byproducts of chemical sterilization which are potential skin irritants. These were reduced to an innocuous level by placing the chambers in flasks containing $250 \mathrm{ml}$ of a hypotonic solution of $0.015 \mathrm{M}$ ${ }^{1}$ Falcon Plastics, Los Angeles, Calif. $17 \times 100 \mathrm{~mm}$ tube no. 2001.

${ }^{2}$ Fellows-Testagar Co., 1354 W. Lafayette St., Detroit, Mich. 48226. A $5 \%(\mathrm{v} / \mathrm{v})$ solution was prepared in $0.15 \mathrm{M}$ saline containing $0.2 \mathrm{M}$ $\mathrm{NaHCO}_{3}$. phosphate-buffered saline at an initial $p \mathrm{H}$ of 7.4 and osmolar concentration of $275 \mathrm{mOsm} / \mathrm{l}$., and dialyzing for 60 hours at $5^{\circ} \mathrm{C}$. After dialysis the average $p \mathrm{H}$ and osmolarity of the chamber contents was 7.35 and 290 $\mathrm{mOsm} / 1$.

Bacterial antigens were prepared by harvesting individual 24-hour Kligler iron-agar slant cultures of E. coli ${ }^{3} 014,0119$, and $0119:$ B14. These were placed in saline with mean concentrations of two million organisms per mm. ${ }^{3}$ Portions of these bacterial suspensions, each of $0.5 \mathrm{ml}$ plus $1.0 \mathrm{ml}$ of saline, were then treated identically the same as was the colon homogenate described above.

Colon was exposed to $E$. coli by mixing $0.5 \mathrm{ml}$ of saline, $0.5 \mathrm{ml}$ of $E$. coli suspension, and $0.5 \mathrm{ml}$ of colon homogenate. This product was then incubated and sterilized in the same manner as the separate colon and E. coli suspensions.

TESTING PROCEDURE Each patient received simultaneous adjacent injections of colon homogenate, $E$. coli, and colon mixed with $E$. coli. Autologous colon was used in each case, and there was no cross-testing with colon tissue. The volar surfaces of the patient's forearms were wiped with alcohol and air-dried and then injected intradermally with $0.1 \mathrm{ml}$ aliquots of the test solutions using a tuberculin syringe with 25 gauge needle. In six of the patients companion injections of the bacterialactivated colon were made through a Millipore ${ }^{4}$ Swinny filter attachment to prevent particles larger than $0.22 \mu$ from being injected.

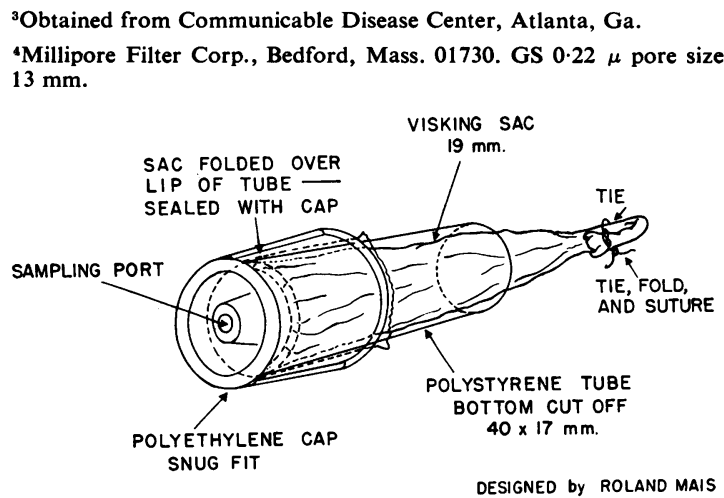

FIG. 1. Dialysis chamber. 


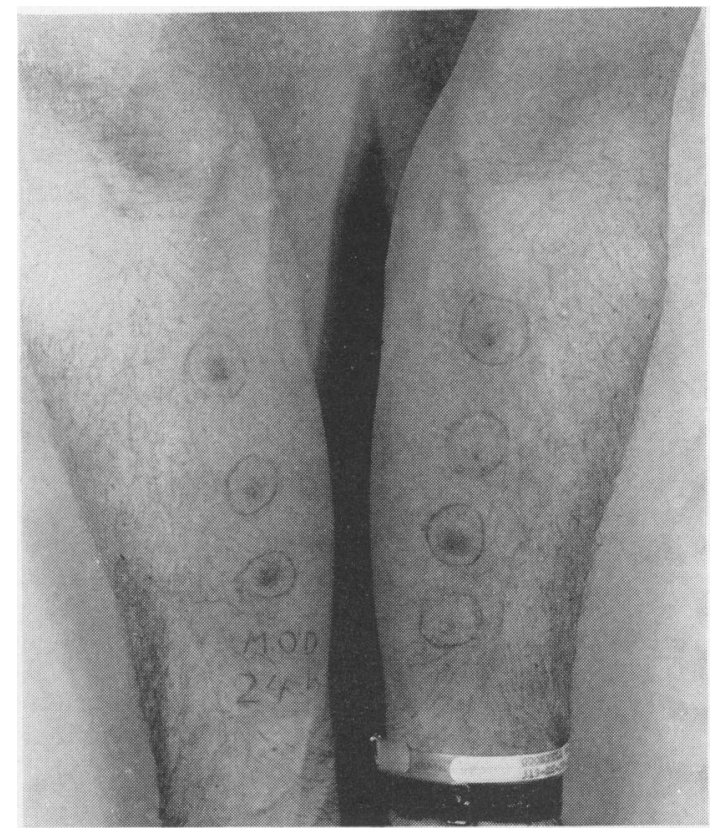

FIG. 2. Patient's forearms after injection of antigens, showing positive areas (1 and 3) on both arms.

The presence and degree of induration was noted and the arms were photographed two, 24, 48, and 72 hours after injection (Fig. 2). At this time a biopsy of the injected site was usually performed. Biopsy specimens were fixed in formalin, processed routinely, and stained with haematoxylin and eosin.

Injected areas were considered positive if two criteria were fulfilled: (a) induration which gradually increased and reached a minimum diameter of $5 \mathrm{~mm}$, and (b) the presence of perivasculitis, eosinophils, and round cell infiltration in the biopsy specimen.

Results I As shown in Table I, none of the patients reacted to injected autologous colon. In contrast, a positive reaction, maximal in 24 to 48 hours, was seen in every instance where live $E$. coli was incubated with colon tissue. This was true for all three $E$. coli species, and occurred in 10 instances (in six patients) in whom no reaction was caused by $E$. coli or colon alone. Material which gave a positive reaction when injected directly into the skin caused no reaction when passed through the Millipore filter.

These observations led us to determine the need for direct bacterial contact in the alteration of colon homogenate.

PREPARATION OF ANTIGENS II One $\mathrm{ml}$ of colon homogenate, secured as in I, was sterilized with Betaprone and dialyzed against the phosphate-buffered saline solution for 60 hours at $27^{\circ} \mathrm{C}$. One $\mathrm{ml}$ of colon homogenate was treated as above, but an inoculum of approximately $2 \times 10^{9}$ viable $E$. coli $0119:$ B 14 organisms was added to the $250 \mathrm{ml}$ of saline dialysant. This allowed bacterial products having a diffusional size commensurate with the average pore diameter of $48 \mathrm{~A}$ to penetrate the dialysis chamber membrane and come into contact with the colon tissue.

A control dialysis chamber was filled with isotonic saline and Betaprone and dialyzed against $250 \mathrm{ml}$ of phosphate-buffered saline containing $2 \times 10^{9}$ viable E. coli 0119 : B 14 organisms.

Cultures of all the inoculates were taken at the time of intradermal injection to confirm separation of the contents of the dialysis chambers from the bacteria in the phosphate-buffered saline dialysant.

RESUlTS II As shown in Table II, no reaction was caused by colon homogenate dialyzed against saline, or by the bacterial diffusate alone. However, colon tissue dialyzed against the bacterial suspensions caused a positive reaction in all but two experiments.

A final investigation was made to show the skin reaction to autologous colon not treated with Betaprone or dialysis.

PREPARATION OF ANTIGENS III Rectal mucosa, secured,

TABLE I

SKIN REACTION TO ANTIGENS I

\begin{tabular}{|c|c|c|c|c|c|c|c|c|}
\hline \multirow[t]{2}{*}{ Patient } & \multirow[t]{2}{*}{ Diagnosis } & \multirow{2}{*}{$\begin{array}{l}\text { Colon } \\
\text { Alone }\end{array}$} & \multicolumn{3}{|c|}{ E. coli Alone } & \multicolumn{3}{|c|}{ Colon in Contact with E. coli } \\
\hline & & & 014 & 0119 & $0119: B 14$ & 014 & 0119 & $0119: B 14$ \\
\hline F.Y. & Ulcerative colitis ${ }^{1}$ & - & + & ND & + & + & ND & + \\
\hline W.D. & Ulcerative colitis ${ }^{1}$ & - & - & ND & - & + & ND & + \\
\hline A.G. & Ulcerative colitis ${ }^{1}$ & - & - & ND & - & + & ND & + \\
\hline E.E. & Ulcerative colitis & - & + & - & - & + & + & + \\
\hline J.W. & Ulcerative colitis & - & - & + & + & + & + & + \\
\hline C.B. & Normal & - & + & ND & + & + & ND & + \\
\hline J.D. & Normal & - & + & ND & - & + & ND & + \\
\hline B.S. & Normal & - & + & $-t$ & + & + & + & + \\
\hline R.D. & Normal & - & - & + & - & + & + & + \\
\hline
\end{tabular}

${ }^{1}$ On Azulfidine therapy.

+ Positive reaction (see text).

- Negative reaction.

ND Not done. 
washed and homogenized as in I and II, was then injected without further treatment.

RESULTS III Three normal individuals and three patients with ulcerative colitis failed to react to injected autologous colon homogenate.

TABLE II

SKIN REACTION TO ANTIGENS II

\begin{tabular}{llccc} 
Patient & Diagnosis & $\begin{array}{l}\text { Colon } \\
\text { Alone }\end{array}$ & $\begin{array}{l}\text { Saline } \\
\text { E. coli } \\
\text { Diffusate }\end{array}$ & $\begin{array}{l}\text { Colon } \\
\text { E. coli } \\
\text { Diffusate }\end{array}$ \\
\hline M.Z. & Normal & - & - & + \\
I.W. & Normal & - & - & + \\
H.B. & Normal & - & - & + \\
T.S. & Normal & - & - & + \\
R.D. & Normal & - & - & - \\
F.R. & Normal & - & - & + \\
A.H. & Ulcerative colitis & - & - & + \\
K.S. & Ulcerative colitis & - & - & + \\
O.H. & Sarcoid & - & - & - \\
+Positive reaction (see text). & & & \\
- Negative reaction. & & &
\end{tabular}

DISCUSSION

The data suggest that the general population is sensitive to autologous colon which has been altered by enteric bacteria. We found no sensitivity to autologous colon not exposed to bacterial action in vitro. The native colon homogenates contained bacteria, but in low concentration. Twenty-four hour cultures of the homogenates before injection showed no growth on blood agar and eosin methylene blue agar; after 10 days at $5^{\circ} \mathrm{C}$ homogenate cultures showed counts of less than 10,000 colonies/ $\mathrm{ml}$. The low bacterial content of the native colon homogenates is also indicated by absence of infection in six instances (colon antigen III) in which this was injected without sterilization by Betaprone.

Betaprone is reported to be an effective chemical sterilizing agent. None of the patients injected with bacterial concentrates or other material which had been treated with Betaprone developed clinical evidence of local infection, and none of 68 skin biopsy specimens showed micro-abscesses or other histological evidence of infection. The sterilization of biological material is accomplished by Betaprone without alteration of antigenicity (Hartman and LoGrippo, 1957). To confirm this, the $E$. coli inoculates were tested with specific rabbit antisera after treatment with Betaprone and dialysis. The treated bacterial suspensions retained their antigenic specificity and potency, as verified by positive agglutination tests (Ewing, 1963). The possibility that Betaprone altered colon antigenicity is minimized by the results (untreated colon) of the experiment with antigen III. In all our patients, sites into which Betaprone-treated material was injected developed a diffuse, non-tender, non-pruritic erythema which appeared within six hours and cleared in 24 to 48 hours. This did not interfere with recognition of superimposed allergic reactions, or histological evaluation at 72 hours.

The second set of experiments indicated that colon tissue was altered by a bacterial product capable of passing through a membrane of $48 \mathrm{~A}$ pore size. Lytic enzymes, such as carbohydrases and peptidases present in bacteria (Strominger and Ghuysen, 1967), could alter tissue, and bacterial enzymes could penetrate the membrane we used (Craig, 1964). One may speculate that the activating factor is a bacterial enzyme or hapten which alters the colonic tissue. A bacterial endotoxin is any one of the enormous class of somatic antigens of Gram-negative bacteria, which are large macromolecular complexes made up largely or entirely of polysaccharides and lipids (Thomas, 1961). Conceivably, one of these is a factor in the alteration of colon tissue. The ability of the Millipore filter used to block the colon antigen $I$ indicates that the antigenic product is larger than $0.22 \mu$.

Recent evidence suggests that a delayed sensitivity reaction is an active stimulatory process in a sensitized individual re-exposed to antigenic material (Leskowitz, 1967). The skin reaction we observed fulfilled several criteria for a delayed-type sensitivity reaction (Humphrey, 1967). It began as an inflammatory response to locally introduced antigens, developed gradually, and was characterized in its later stages by round cell infiltration. Finally, the negative reaction by a patient with impaired delayed sensitivity due to sarcoidosis also supports this interpretation. It is less likely, but also possible, that the skin reaction caused by colon treated with $E$. coli filtrates may be due to pharmacologically active agents in the extract, and not to a delayed hypersensitivity reaction.

Despite the similar reaction in our two patient groups, one is tempted to speculate that an aberrant response is a factor in the pathogenesis of ulcerative colitis. A possible connexion would be established by demonstrating that the enzyme inhibitor Azulfidine, of known efficacy in the treatment of ulcerative colitis (Zetzel, 1964), prevents the bacterial alteration of colon tissue; these experiments are now in progress.

\section{SUMMARY}

Intradermal skin tests using autologous colon, colon exposed to bacterial accion, and E. coli were performed in seven patients with active ulcerative colitis, 10 normal individuals, and one patient with 
sarcoidosis. Autologous colon caused no reaction, but a positive reaction which was grossly and histologically of the cell-mediated immune type followed the injection of the same amount of colon antigen pretreated with $E$. coli or an $E$. coli filtrate. The two larger groups of patients reacted similarly; however, the implications in the pathogenesis of ulcerative colitis are discussed.

We thank the Medical Illustration Service at Hines VA Hospital and Mrs Carole Weisbecker for their assistance.

\section{REFERENCES}

Craig, L. C. (1964). Differential dialysis. Science, 144, 1093-1099.

Dragstedt, L. R., Dack, G. M., and Kirsner, J. B. (1941). Chronic ulcerative colitis. A summary of evidence implicating Bacterium necrophorum as an etiologic agent. Ann. Surg., 114, 653-662.
Ewing, W. H. (1963). CDC Laboratory Manual. US Dept. Health Education, and Welfare, Atlanta, Georgia.

Hartman, F. W., and LoGrippo, G. A. (1957). Beta-propiolactone in sterilization of vaccines, tissue grafts, and plasma. J. Amer. med. Ass., 164, 258-260.

Humphrey, J. H. (1967). Cell-mediated immunity-general perspectives. Brit. med. Bull., 23, 93-97.

Kirsner, J. B. (1965). The immunologic response of the colon. $J$. Amer. med. Ass., 191, 809-814.

Leskowitz, S. (1967). Mechanism of delayed reactions. Science, $155,350-352$.

Perlmann, P., Hammarström, S., Lagercrantz, R., and Gustafsson, B. E. (1965). Antigen from colon of germfree rats and antibodies in human ulcerative colitis. Ann. N.Y. Acad. Sci., 124, 377-394.

Strominger, J. L., and Ghuysen, J. M. (1967). Mechanisms of enzymatic bacteriolysis. Science, 156, 213-221.

Thomas, L. (1961). Role of endotoxins in immune and vascular reactions. Gastroenterology, 40, 364-369.

Zetzel, L. (1964). Treatment of ulcerative colitis. New Engl. J. Med., 271, 891-895. 